CUAJ honors its members and friends who have passed away. We invite colleagues of the deceased to submit brief remembrances. Please limit your notice to 200 words. Send your notice to journal@cua.org or fax it to 514-395-1664.
Cite as: Can Urol Assoc J 2021;15(1):E79. http://dx.doi.org/10.5489/cuaj.7105

\section{James Wilson Grahame}

The CUA was saddened to hear of the passing of Dr. James Wilson Grahame, who died peacefully on November 6, in Victoria, BC. Dr. Wilson leaves to mourn his loving wife Jane, and their blended family of six children, Michael, Jennifer, Stephanie, Timothy, Penny, Oliver; and six grandchildren, Rileigh, Storme, Skyler, Laighton, Caitlin, Dylan.

Born in Northern Ireland, Dr. Wilson studied medicine at Queen's University in Belfast before emigrating to Canada in 1965, where he undertook a urology residency in Winnipeg, MB. In 1976, he relocated to Vancouver, where he practiced until his retirement in 1993.

Following retirement, Dr. Wilson pursued his many passions, including sailing, travelling, gardening, guitar, and most importantly spending time with family.

He left an unforgettable impression on the many lives he touched throughout his life and he will be missed. 